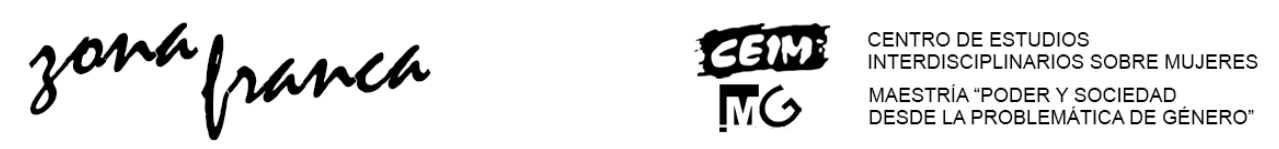

\title{
Archivo transfeminista, poéticas y experiencias sensibles
}

\author{
Laura Cabezas * \\ Constanza Penacini **
}

\section{Resumen}

El presente artículo propone repensar el concepto de archivo, desde una mirada transfeminista, en tres obras contemporáneas, con diferentes soportes: la película Madame Satã de Karim Aïnouz, la muestra "Siempre estuvimos ahí" organizada por el Archivo de Memoria Trans, ubicado en el Centro Cultural Haroldo Conti, y la novela Las malas de Camila Sosa Villada. Entendemos que estos tres artefactos culturales problematizan el dispositivo archivo entablando una discusión poético-política necesaria para poner en cuestión las imágenes cristalizadas de las subjetividades travestis trans que emergen de las secciones policiales, los informes médicos y/o el carnaval. Así, de los primeros años del siglo XXI a fines de la primera década, de Brasil a Argentina, del arte visual a la literatura, la serie se sostiene sobre la urgencia de construir un nuevo archivo para la comunidad travesti trans, sacar sus cuerpos de la excepcionalidad y disputar una nueva visibilidad guiada por lo cotidiano y lo afectivo. No obstante, sostendremos que este nuevo reparto de lo visible no implica el borramiento de la exclusión. Ni víctimas ni delincuentes, son sobrevivientes que también se muestran como sujetos afectivxs, deseantes, históricxs, insertxs en una comunidad materialmente imaginada. Es por eso que el archivo creado deberá dar cuenta de la norma y la violencia, contestarla, recorrerla a contrapelo, proyectar nuevas sensaciones y trazar identidades y cuerpos alternativos.

Palabras clave: archivo transfeminista - Madame Satã - Archivo de la Memoria Trans - Las malas

\footnotetext{
*Universidad de Buenos Aires. Contacto: laura.czas@gmail.com

** Universidad de Buenos Aires- Consejo Nacional de Investigaciones Científicas y Técnicas. Contacto: cpenacini@gmail.com
}

Cabezas, Laura; Penacini, Constanza. "Archivo transfeminista, poéticas y experiencias sensibles" en Zona Franca. Revista del Centro de estudios Interdisciplinario sobre las Mujeres, y de la Maestría poder y sociedad desde la problemática de Género, №28, 2020 pp. 365-386. ISSN, 2545-6504 Recibido: 1 de agosto 2020; Aceptado: 15 de octubre 2020

Revista Zona Franca- Centro de estudios interdisciplinario sobre las mujeres (CEIM)- Maestría poder y sociedad desde la problemática de género (MG), Rosario, Argentina. ISSN, 2545-6504 http://zonafranca.unr.edu.ar/index.php/ZonaFranca| Número 28 (2020). 


\section{Trans archives, poetics and sensitive experiences}

\section{Abstract}

This article proposes to rethink the concept of archive, from a transfeminist perspective, in three contemporary works, with different supports: the film Madame Satã by Karim Aïnouz, the exhibition "We were always there" organized by the Trans Memory Archive, located in the Centro Cultural Haroldo Conti, and the novel Las malas by Camila Sosa Villada. We understand that these three cultural artifacts problematize the archive device by engaging in a poetic-political discussion necessary to question the crystallized images of transvestite subjectivities that emerge from the police sections, medical reports, and/or the carnival. Thus, from the first years of the 21st century to the end of the first decade, from Brazil to Argentina, from visual art to literature, the series is based on the urgency of building a new archive for the transvestite community, removing their bodies from exceptionalism and contesting a new visibility guided by the everyday and the affective. However, we will maintain that this new distribution of the visible does not imply the erasure of exclusion. Neither victims nor criminals, they are survivors who also show themselves as affective, desiring, historical subjects, inserted in a materially imagined community. That is why the archive created must account for the norm and violence, answer it, run it against the grain, project new sensations and trace alternative identities and bodies.

Key words: archivo - transfeminism - Madame Satã - Archivo de la Memoria Trans - Las malas

\section{Cárcel y carnaval}

Empecemos con dos escenas. Un cuerpo negro vulnerable y vulnerado, de aproximadamente treinta años, sentado y golpeado, mira a cámara. Detrás, una pared blanca, descascarada, rugosa, enmarca la precariedad de la imagen. La sombra esconde mitad de su rostro, pero no impide que se vean las marcas de la violencia institucional inscriptas en la piel. Mientras, una voz en off rompe el silencio e informa que el acusado

es un criminal muy conocido en este distrito policíaco como alborotador.

Frecuenta el barrio de Lapa y sus alrededores. Es un pederasta pasivo que se afeita las cejas y adopta actitudes femeninas, incluso cambiando la

Revista Zona Franca- Centro de estudios interdisciplinario sobre las mujeres (CEIM)- Maestría poder y sociedad desde la problemática de género (MG), Rosario, Argentina. ISSN, 2545-6504 http://zonafranca.unr.edu.ar/index.php/ZonaFranca| Número 28 (2020).

Página 366 
propia voz. (...) No tiene buenos modales. Habla de forma maleducada y usa en su lenguaje, palabras propias de su ambiente. Es poco inteligente. Odia la convivencia en sociedad por ver que le rechaza por sus vicios. Siempre se le ve con pederastas, prostitutas, proxenetas, y otras personas del más bajo nivel social. Alardea de poseer riquezas, pero como no tiene trabajo digno, ese dinero solo puede ser producto de actividades repulsivas o criminales. (...) Es un individuo calculista, propenso al crimen y por todo esto, supone una gran amenaza para la sociedad. Rio de Janeiro, Distrito Federal, a los 12 días del mes de mayo de 1932 (1:17-2:42).

Así comienza Madame Satã, la película dirigida por Karim Aïnouz, del año 2002². Ambientada en el Brasil de los años treinta, el film relata la vida del transformista João Francisco dos Santos (1900-1976) que, como se lee en fragmento citado, enfrenta la pobreza, las normas morales y sociales de su tiempo, y la persecución policial. Una vida desnuda, y al desnudo, materializa el legajo leído que aúna dos imaginarios amenazantes: el del malandro y el del pederasta afeminado. Sin embargo, es el desvío en su forma de performatizar el género masculino el que sostiene la criminalidad, su presunto odio a esa sociedad que le rechaza por "vicioso", es decir, por alterar los cánones hegemónicos en la conformación de la identidad y por establecer vínculos afectivos que dotan de otros sentidos a la familia como institución burguesa.

Desde la intersección entre género, raza y clase, la narrativa fílmica se nutre de los archivos de la violencia y del cine de Hollywood para ahondar en el margen y, desde ahí, contar la conversión de Santos en Madame Satã, una reconocida estrella performática que deviene sujeto presidiario luego de asesinar a un policía. La riqueza de la representación propuesta en la película radica en, como señala Tania Medalla Contreras (2012), que escapa a los polos de la idealización y la estigmatización de las identidades marcadas por la exclusión, pues "João, da muestra clara, más allá de la violencia de la que es objeto, de un ejercicio de libertad

2 Las reflexiones que siguen se enmarcan dentro de los debates desarrollados en la cátedra de Literatura Brasileña (FFyL, UBA). Sobre el tema, ver el teórico de Gonzalo Aguilar en: https://www.youtube.com/watch?v=l-9d-OYmFq0

Revista Zona Franca- Centro de estudios interdisciplinario sobre las mujeres (CEIM)- Maestría poder y sociedad desde la problemática de género (MG), Rosario, Argentina. ISSN, 2545-6504 http://zonafranca.unr.edu.ar/index.php/ZonaFrancal Número 28 (2020). 
y dignidad radical frente a la sociedad que los excluye" (8). En este sentido, quizá sea el carnaval el momento que mejor exprese la liberación de los cuerpos y, por eso, es nuestra segunda escena elegida, la que da cierre a la película. Pero lo interesante es que el final retoma el comienzo, esa imagen en primer plano con el informe policial de fondo, para luego dar lugar a los brillos de la carnavalización y a la propia voz de la protagonista:

Viví presa durante diez años en el castillo de las Arabias. Una princesa de nombre Jamacy. Debido a la envidia, la reina maléfica había aprisionado a la joven princesa que volvía triste y solitaria hasta que un día de carnaval, un caballero en su camello liberó a la princesa que corrió a pie hasta llegar a su Lapa querida. La princesa se apresuró a preparar su disfraz para el desfile de los Cazadores de Venados. Jamacy vestida desfiló brillantemente en el carnaval del 42. Y Jamacy se hizo conocida para el resto del mundo como Madame Satã. (1:30:05-1:30:51)

La voz se superpone con la música fuerte, los movimientos de un cuerpo radiante, al que ya no lo cubren las grafías sombrías del odio, sino las telas coloridas y las piedras brillantes que recrean una subjetividad en trance. Es una pausa, un intervalo de la violencia, porque como se lee en los últimos segundos del film, Madame Satã "ganó muchos concursos y fue encarcelado muchas veces más" (1:31:31). Esta última frase condensa una poética y una política del archivo en relación con el universo trans. Aïnouz detecta muy bien cómo del archivo médicopolicial y del archivo del carnaval emergen dos experiencias subjetivas que, si bien contrapuestas, encuentran su punto de contacto en la imagen pública y espectacularizada del cuerpo travestido en el contexto latinoamericano.

"El archivo es ante todo la ley de lo que puede ser dicho, el sistema que rige la aparición de los enunciados como acontecimientos singulares", afirma Michel Foucault (1997: 219) en La arqueología del saber. Esto quiere decir que el archivo no sería en sentido estricto el conjunto de documentos que una cultura conserva como parte del relato de su pasado ni tampoco las instituciones encargadas de

Revista Zona Franca- Centro de estudios interdisciplinario sobre las mujeres (CEIM)- Maestría poder y sociedad desde la problemática de género (MG), Rosario, Argentina. ISSN, 2545-6504 http://zonafranca.unr.edu.ar/index.php/ZonaFranca| Número 28 (2020).

Página 368 
resguardarlos. Madame Satã trabaja con la memoria del cuerpo trans y su decibilidad en diferentes momentos históricos, la década del treinta donde se ubica la vivencia de João Francisco dos Santos, los años setenta cuando su figura es reivindicada y los dos mil cuando se estrena la película. Nos queremos detener en esta última inscripción temporal para reflexionar sobre el vínculo entre el archivo travesti trans, el poder y la experimentación emancipatoria que se produce en este nuevo milenio. Siguiendo a Suely Rolnik (2008), entendemos que el uso del dispositivo archivo crea las condiciones necesarias para que esas prácticas y cuerpos trans activen "experiencias sensibles en el presente, necesariamente distintas de las que se vivieron originariamente, pero con el mismo tenor de densidad crítica" (10). ¿Cómo cristalizan un concepto y construyen una subjetividad los archivos de la normalización? ¿Cuáles son las estrategias que pueden servir en la lucha contra esa interpretación? ¿Qué rescatar para plantear un recorrido diferente y crítico? Y también, retomando nuevamente a Rolnik, el siguiente artículo se preguntará: ¿qué políticas de deseo sirven de impulso a las diferentes iniciativas de inventario y sus modos de presentación?

Según afirma Ainouz, para él no era tan importante explicar el mito de Madame Satã o imponerle un origen, sino "retratar al personaje antes de la creación del mito. Quería compartir su intimidad" (apud Contreras 2012). Esta elección por recrear lo íntimo y familiar; lo que escapa a los mecanismos de control; lo que no se ve, pero está ahí, es una decisión poético-política que permite poner en relación Madame Satã con la conformación del Archivo de Memoria Trans en 2017 y la publicación de Las malas de Camila Sosa Villada en 2019. De los primeros años del siglo XXI a fines de la primera década, de Brasil a Argentina, del arte visual a la literatura, la serie se sostiene sobre la urgencia de construir un nuevo archivo para la comunidad travesti trans, sacar sus cuerpos de la excepcionalidad -ya sea la sección policial, el informe médico o el baile de carnaval-y disputar una nueva visibilidad guiada por lo cotidiano y lo afectivo. Ahora bien, este nuevo reparto de lo visible no implica el borramiento de la exclusión. Ni víctimas ni delincuentes, son sobrevivientes que

Revista Zona Franca- Centro de estudios interdisciplinario sobre las mujeres (CEIM)- Maestría poder y sociedad desde la problemática de género (MG), Rosario, Argentina. ISSN, 2545-6504 http://zonafranca.unr.edu.ar/index.php/ZonaFranca| Número 28 (2020). 
también se muestran como sujetos afectivxs, deseantes, históricxs, insertxs en una comunidad materialmente imaginada. Así, el archivo creado debe dar cuenta de la norma y la violencia, contestarla, recorrerla a contrapelo, proyectar nuevas sensaciones, y trazar identidades y cuerpos alternativos.

De este modo, si el AMT recupera fotografías del afecto, invisibilizadas para la sociedad, y las organiza a partir del montaje con cartas privadas y legajos policiales, la novela de Camila Sosa Villada cruza la autobiografía con la ficción para poder narrar la historia de su propia manada travesti, desde un realismo maravilloso o marabrilloso que no esconde las marcas violentas del dolor y el sufrimiento. Así como Madame Satã transformaba la prisión en castillo y se autopercibía como una joven princesa que, caída en desgracia por la envidia de la reina malvada, terminaba siendo rescatada por un príncipe que la conducía al carnaval, Camila, la protagonista de Las malas, delinea una cartografía cordobesa for export con travestis mutantes que transforman su exotismo en signo político abrazando comunitariamente el costado sensible de las subjetividades marginalizadas. Consideramos, en este sentido, que estas tres experiencias estéticas contribuyen a la formación de un archivo transfeminista latinoamericano que, en su gesto poéticopolítico, inventa otros principios de clasificación y organización, corporales, carnales y sensorialmente expresivos, para contar al mundo y contarse a sí mismas su historia colectiva.

\section{"Siempre estuvimos ahi"}

"Creo que las travestis tenemos una historia para contar y para hacer. Es decir, experiencias en primera persona para contraponer a los discursos que han circulado sobre nosotras", apunta Lohana Berkins (2006) en un Congreso de Historia de las mujeres y Estudios de género realizado en la ciudad de Córdoba. En su ponencia, Lohana rastrea la irrupción y el uso del término "travestismo" en el espacio público a partir de los "discursos biomédicos, policiales, sociológicos, jurídicos y periodísticos" que lo condenaron a ser asociado siempre al mundo del delito, la

Revista Zona Franca- Centro de estudios interdisciplinario sobre las mujeres (CEIM)- Maestría poder y sociedad desde la problemática de género (MG), Rosario, Argentina. ISSN, 2545-6504 http://zonafranca.unr.edu.ar/index.php/ZonaFranca| Número 28 (2020). 
enfermedad y el escándalo: "el término 'travesti' ha sido y sigue siendo utilizado como sinónimo de sidosa, ladrona, escandalosa, infectada, marginal. Nosotras decidimos darle nuevos sentidos a la palabra travesti y vincularla con la lucha, la resistencia, la dignidad y la felicidad", sentencia Lohana Berkins. Así, esas "experiencias en primera persona" y ese "nosotras" cifran la posibilidad de conformar un archivo diferente para la comunidad travesti trans, que no se reduzca a los legajos o crónicas policiales ni a los informes médicos o las actas de defunción; tampoco a sus participaciones en el carnaval que, como ya vimos, configuran el único momento de libertad y comunión con una sociedad que antes o después de la fiesta las discrimina. Esos documentos, que emanan sentidos, saberes y cuerpos violentados, hablan de y por ellas. ¿Pero cómo acceder a sus voces y escuchas, a sus imágenes propias, a los afectos que no caben en los archivos de la excepción como regla?

A partir de su proyecto genealógico, Michel Foucault (1992) llama la atención sobre aquello que pasa desapercibido por no tener historia: los sentimientos, el amor, la conciencia, los instintos, que, sin embargo, se encuentran donde menos se los espera y señalan con su ausencia aquellos momentos en que no tuvieron lugar. Contar y hacer historia, como propone Lohana Berkins, implica necesariamente mostrar ese no tener lugar de los enunciados afectivos que diseñan una realidad íntima, cotidiana y familiar de las vidas travestis que contrasta con el relato público del "travestismo" alojado en el archivo policial, médico y del carnaval. De ahí la emergencia por visibilizar esos momentos privados, obturados para la sociedad, que en general eran vividos clandestinamente -porque la persecución policial y el hostigamiento no daban tregua-, en el interior de los hogares o en las afueras de la ciudad.

"Vida cotidiana" justamente es el título de una de las cuatro secciones de la muestra digital "Siempre estuvimos ahí", que el Archivo de la Memoria Trans organizó en el sitio web de la Cámara de Diputados de la Nación, entre el 21 y el 30 de julio de este año. La serie de fotografías invita a recorrer "las sencillas 
ceremonias de todos los días": el estar en casa, darle cuerpo a una familia y a un hogar. Son imágenes de chicas trans escribiendo, peinándose, viajando, sonriendo en la playa, jugando a las cartas, mirándose entre ellas. Fotografías que, como leemos en la presentación,

[c]apturan lo íntimo, lo mínimo, lo que pasa desapercibido. Un beso robado a la mañana, una pausa en el juego, un momento de descanso o de aburrimiento. La memoria trans conserva estas imágenes como un testimonio de que, como todas y todos, ellas siempre estuvieron ahí.

Si la memoria ocupa un rol central en todo archivo, en el caso de un archivo trans la memoria se reconstruye desarmando los relatos legados por los archivos de la normalización, el espectáculo y el odio. La memoria trans da testimonio de esas vivencias que siempre estuvieron, pero estaban socialmente tachadas. Porque no se trata solamente de visibilizar lo negado, sino de posibilitar una subjetividad que emerja de ese archivo que están construyendo. El "siempre estuvimos ahi" supone una doble operación en el ejercicio de una política archivística: por un lado, documenta materialmente una zona forcluida para las vidas y cuerpos trans; por el otro, le otorga al documento la categoría de sobreviviente. Las fotos suplen a quienes no pueden testimoniar, son un acontecimiento que revela "la posibilidad misma de hablar" (Agamben 2002: 153), con o sin palabras. 


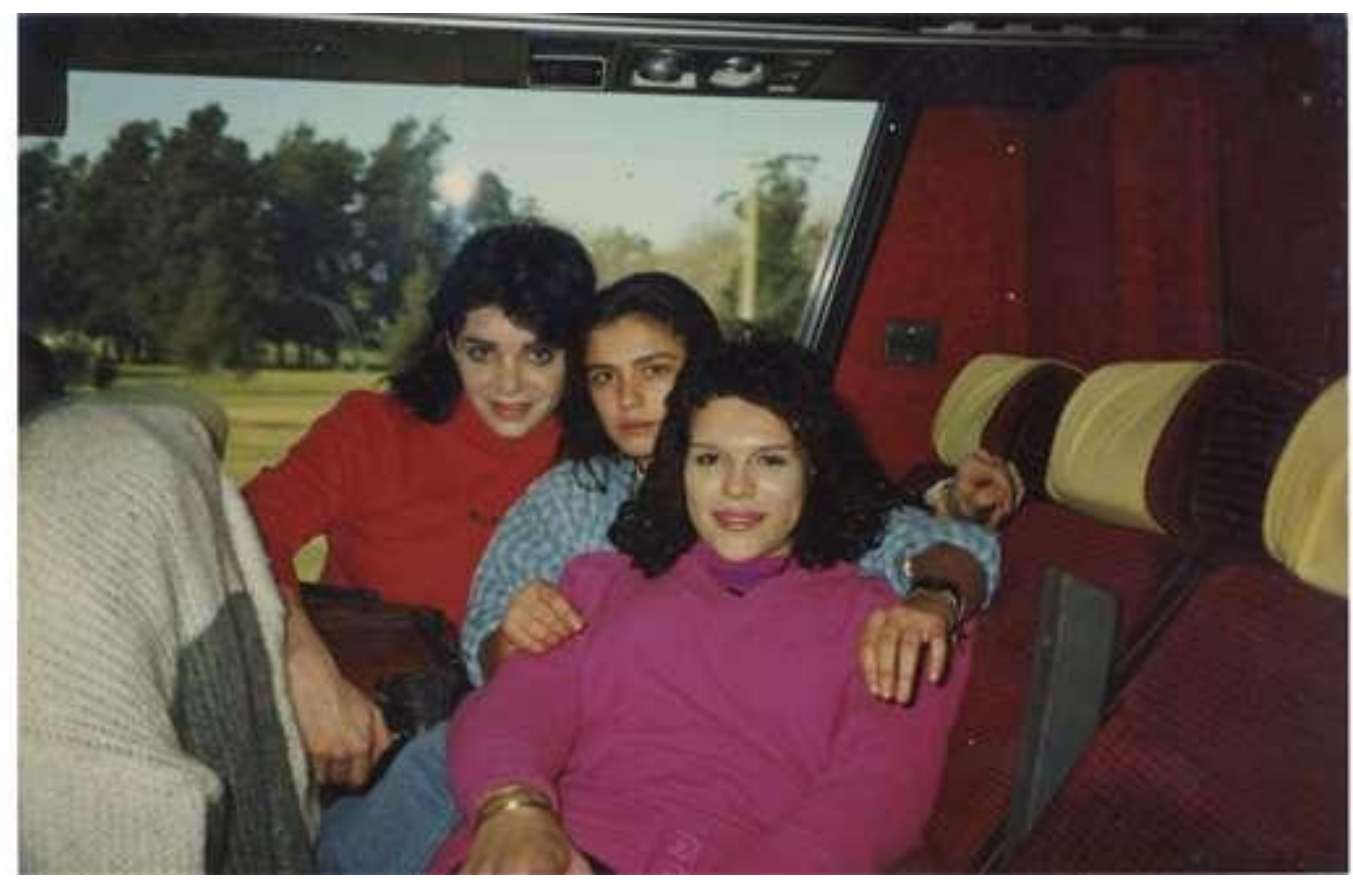

Archivo de Memoria Trans

Desde fines del siglo XIX, la fotografía se configuró como un dispositivo de cohesión y estigmatización, tal como lo muestra Allan Sekula (1986) en "The body and the archive", donde analiza la articulación fundacional entre la fotografía, el caso policial y la emergencia de la criminología. Lo interesante -y perturbadordel artículo es que, además de recorrer con minuciosidad los archivos del positivismo, a través de las metodologías de Bertillon y Galton, que se proponían regular las "desviaciones" sociales, Sekula muestra cómo estos sistemas "are still with us" (62): en las operaciones de los estados de seguridad nacional y en la autoridad del determinismo biológico. Frente a estos mecanismos bionormalizadores, las fotografías del archivo trans y las elegidas para la muestra virtual deslegitiman el estigma de los cuerpos e inauguran un nuevo paisaje visual: "Si bien para nosotras son nuestras fotos familiares de toda la vida, sacadas por nosotras mismas en un ambiente familiar y cotidiano, para la gente son fotos $\sin$ ningún tipo de estigma, cosa a la que no estábamos acostumbradas". En esta declaración-epígrafe de la serie "Vida cotidiana" se condensa el efecto contestatario que deconstruye y reconfigura el archivo trans, a través de la posibilidad de trastocar

Revista Zona Franca- Centro de estudios interdisciplinario sobre las mujeres (CEIM)- Maestría poder y sociedad desde la problemática de género (MG), Rosario, Argentina. ISSN, 2545-6504 http://zonafranca.unr.edu.ar/index.php/ZonaFrancal Número 28 (2020). 
la mirada médico-policial-patriarcal que históricamente se depositó sobre las vidas y cuerpos trans, permitiendo así rearmarla bajo premisas feministas. Como sostiene Cecilia Estalles (2018), fotógrafa e integrante del equipo de trabajo del AMT, en una entrevista a raíz de la primera muestra del archivo en marzo de 2018: si "las imágenes que se conocen sobre la comunidad trans-travesti son las imágenes del fotógrafo con su cámara, sacando fotos hacia una comunidad con su visión" (6:4046), la potencia de las imágenes rescatadas y expuestas radica en asumir la visión en primera persona y hacer que el relato íntimo se vuelva historia colectiva. Es por este motivo que Estalles confía en que el rescate del álbum familiar de las historias de cada compañera, "que son muchas veces similares y todas arman una gran memoria colectiva" (7:07-9), puede intervenir radicalmente en el modo de entender la fotografía y la historia argentina -latinoamericana, agregamos nosotras-, ya que muestran desde un lugar emotivo cuerpos individuales y colectivos trans que no estaban contados o estaban mal contados: contados "por los medios hegemónicos de una manera tremenda" (7:34). Salir de la excepcionalidad como horizonte de representabilidad impuesta y sacarse la propia foto permite entonces la formación de un contrarchivo que no habla en nombre de, sino que es hablado por voces transindividuales. "Siempre estuvimos ahí" es producto de esta opción curatorial que resguarda pero que también relee y pone en cuestión el saber y el poder opresivo que emanaban los archivos normativizadores y biopolíticos. Contra la cristalización, las imágenes devienen vida y movimiento, "ecos de las voces de aquellas que ya no están" (AMT), y nos interpelan.

Al recorrer las imágenes de la vida cotidiana, una de ellas llama nuestra atención. Es la que ilustra la tapa de la novela Las malas, de Camila Sosa Villada, publicada por la editorial Tusquets el año pasado, dentro de la colección Rara avis. La foto captura la diversión del instante, dos chicas travestis galopando un caballo con desparpajo, la que lleva las riendas parece estar gritando sorprendida, la otra la abraza con fuerza, no se le ve la cara, y ambas fusionan su feminidad con el animal, que marcha tranquilo, casi solemne, enmarcado por un paisaje semi rural,

Revista Zona Franca- Centro de estudios interdisciplinario sobre las mujeres (CEIM)- Maestría poder y sociedad desde la problemática de género (MG), Rosario, Argentina. ISSN, 2545-6504 http://zonafranca.unr.edu.ar/index.php/ZonaFranca| Número 28 (2020). 
y sosteniendo sobre sí parte de la manada travesti, que unas páginas más adelante protagonizará el universo ficcional de Sosa Villada. Observamos que ni en los créditos del libro ni en la muestra virtual se revela el origen de la fotografía. ¿Será una de las tantas imágenes compartidas en el grupo de Facebook devenido arcón digital, un recuerdo de alguna caja o álbum familiar legado?

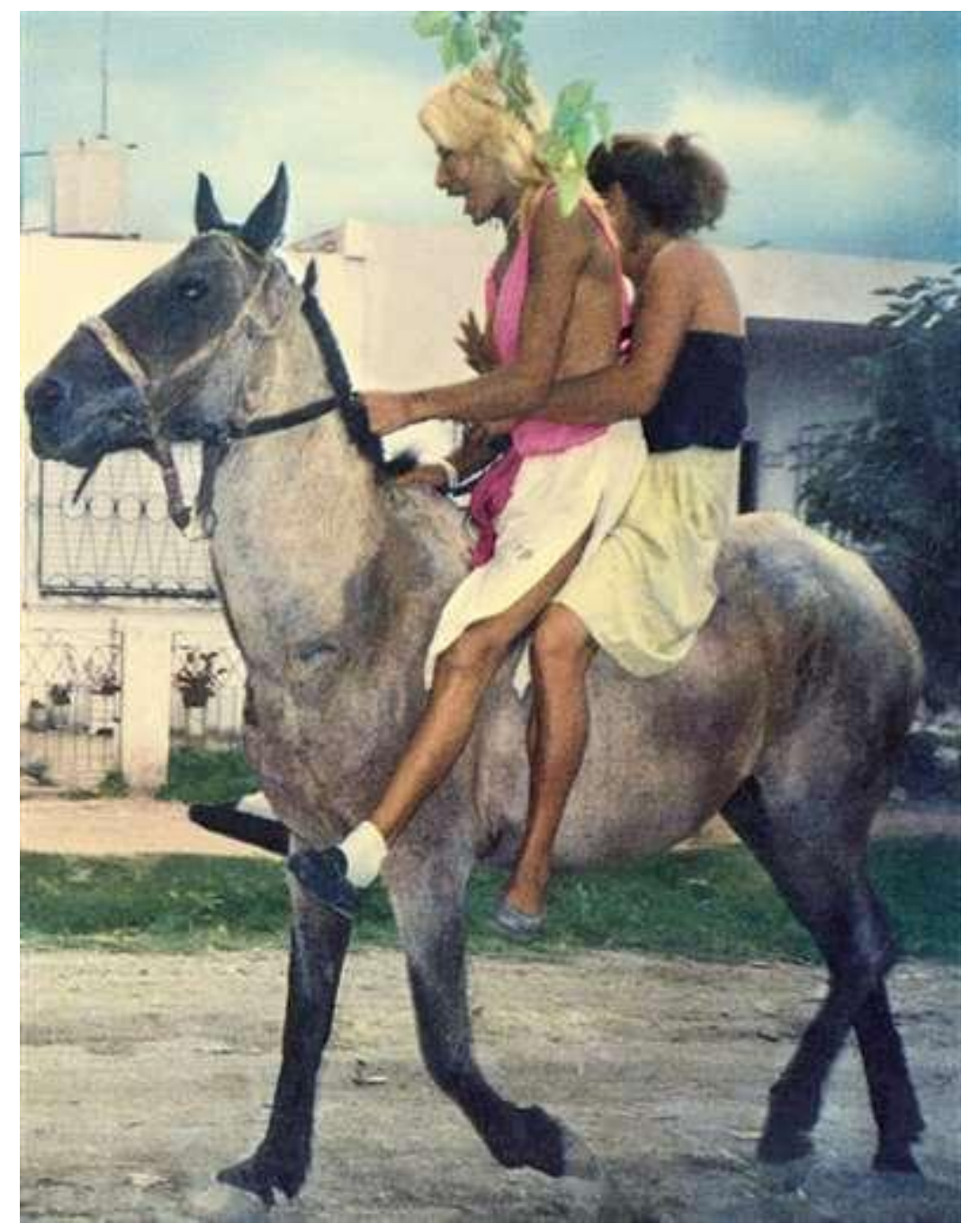

Archivo de Memoria Trans

Revista Zona Franca- Centro de estudios interdisciplinario sobre las mujeres (CEIM)- Maestría poder y sociedad desde la problemática de género (MG), Rosario, Argentina. ISSN, 2545-6504 http://zonafranca.unr.edu.ar/index.php/ZonaFranca| Número 28 (2020). 
El Archivo de la Memoria Trans es un proyecto independiente y autogestivo que, como cuenta Belén Correa, su directora, se genera a partir de un grupo "ultracerrado" de la red social mencionada en el que ingresan contactos, y contactos de contactos, con el objeto de compartir sus objetos guardados y ocultos. Frente a los mecanismos clasificatorios del cuerpo, el archivo rizomático de Facebook organiza sin dominar las imágenes heterogéneas, y deviene un laberinto "compuesto tanto de intervalos y huecos como de material observable" (Didi Huberman 2012: s/p). Cuando Cecilia Estalles llega al grupo buscando información sobre algún travesticidio o transfemicidio para un proyecto fotográfico propio, se encuentra con el material desplegado, y aparece la propuesta de digitalizar y dar a conocer esos documentos. Juntas, Belén Correa y Cecilia Estalles, organizan el material, le dan forma y lo clasifican, a partir de la triple consigna de reconstruir una memoria, acceder a una verdad y exigir justicia. En palabras de Belén, "nosotras estamos en la primera etapa. En la memoria, en tratar de reconstruir esa memoria, de poder descubrirla y hacerla visible para que eso se convierta en una verdad y a partir de ahí poder llegar a la justicia!" (8:05-18). El Archivo de la Memoria Trans, entonces, se presenta en su página oficial como un archivo que se entiende bajo "formas amenazantes" que tienen un "carácter expansivo, abierto, heterogéneo" (AMT). Mediante un enfoque de género (o perspectiva feminista) que les "permite expandir la exploración de las imágenes y ampliar el intercambio para poder confrontar enteramente desde el presente" (ídem). Le reconocen una "potencia en mutación" porque resiste el mal de archivo ${ }^{3}$, buscando las huellas de una memoria cultural acallada. Lejos de los relatos totalizantes y las identidades fijas, el archivo de la AMT se define rupturista, plural, diverso y fractal.

\footnotetext{
${ }^{3}$ A partir de una perspectiva psicoanalítica Jaques Derrida explora los mecanismos por los cuales el recuerdo deja sus huellas materiales, así como la relación arbitraria que hay entre el objeto material y la vida psíquica que es marcada por tal objeto. La conclusión será que el archivo es fundamentalmente imposible ya que, en última instancia, la lógica de todo recuerdo es similar a la de la experiencia traumática, que no puede archivarse ni siquiera en el inconsciente. (Derrida 1997)
}

Revista Zona Franca- Centro de estudios interdisciplinario sobre las mujeres (CEIM)- Maestría poder y sociedad desde la problemática de género (MG), Rosario, Argentina. ISSN, 2545-6504 http://zonafranca.unr.edu.ar/index.php/ZonaFrancal Número 28 (2020). 


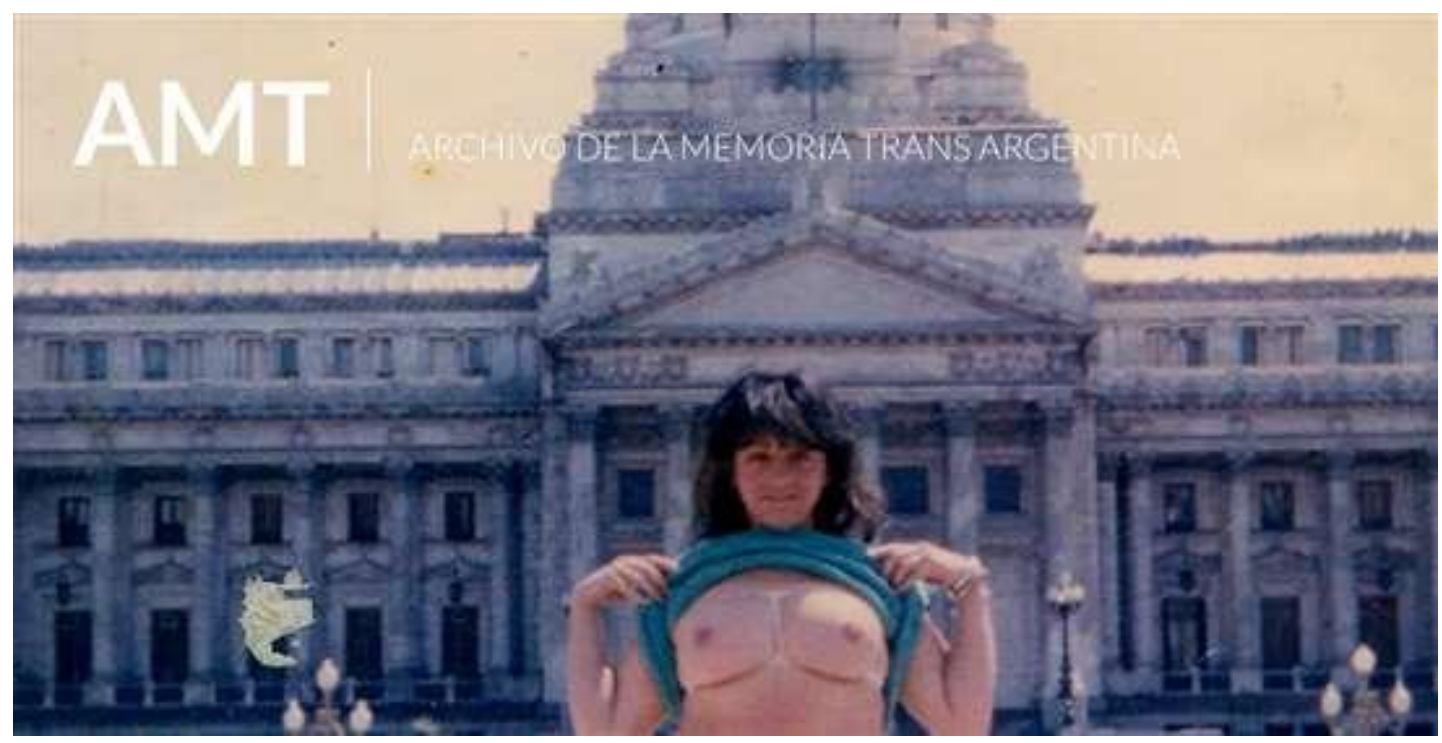

Archivo de Memoria Trans

\section{Divino maravilloso}

Por un lado, entonces, está el archivo de la excepcionalidad que suponen los prontuarios policiales, los legajos judiciales, las historias clínicas, o las crónicas de los escándalos y las fiestas populares como el carnaval. Por otro lado, el de la cotidianeidad, que viene a contradecir esa configuración de la existencia travesti llenando los vacíos, los silencios y el ocultamiento de la vida íntima, afectiva, social que el primer archivo deja afuera. En este sentido, el Archivo de la Memoria Trans se construye contra esa lógica de poder de arconte, institucional, hegemónica y censora, que fija interpretaciones y subjetividades, que produce imágenes y enunciados estancos. Por el contrario, el AMT sigue la lógica del devenir deleuziano: "Su carácter es expansivo, en el sentido de que posee la cualidad de multiplicarse, de pensarse a modo de trama, en forma de red abierta y mutable. También es un proyecto sensible, porque al trabajar directamente con imágenes y escritos cargados de recuerdos, anécdotas, y relatos de la clandestinidad es imposible no verse interpeladx por estas historias omitidas" (AMT).

Revista Zona Franca- Centro de estudios interdisciplinario sobre las mujeres (CEIM)- Maestría poder y sociedad desde la problemática de género (MG), Rosario, Argentina. ISSN, 2545-6504 http://zonafranca.unr.edu.ar/index.php/ZonaFranca| Número 28 (2020). 
Será Las malas, primera novela de la actriz y escritora travesti Camila Sosa Villada, la que logre cruzar ambos archivos y articular todos esos discursos, integrándolos en un relato ficcional de la existencia individual y colectiva travesti. Desde la ficción autobiográfica, Sosa Villada reconstruye la historia de una comunidad de travestis que se nuclean alrededor del personaje de la Tía Encarna, una travesti longeva que funciona como líder y madre de una comunidad de prostitutas, que tienen su parada en el Parque Sarmiento de la Ciudad de Córdoba durante el final de la década del noventa y en los primeros años del dos mil. A partir de algunos datos espacio-temporales es posible situar el relato que, sin embargo, se monta sobre un tiempo mítico y una realidad cruzada por elementos fantásticos y maravillosos, construyendo un mundo con reglas propias y personajes fabulosos. Por todo ello -y lo que sigue-, podemos afirmar que Las malas se inscribe en la tradición del realismo mágico latinoamericano y lo actualiza en clave trans. Sosa Villada recupera la operación que algunos escritores realizaron durante la década del sesenta inaugurando una narrativa propia de América Latina, que la dotó de una lengua y una identidad única y singular en el concierto de la literatura mundial, siempre organizada desde una mirada eurocéntrica:

\begin{abstract}
Comenzó a llamarse realismo mágico o real-maravilloso, estilo o sensibilidad que postulaba que la realidad era en sí misma asombrosa, con lo cual el escritor latinoamericano podía ser al mismo tiempo un innovador del lenguaje (al inspirarse en la estética del tiempo roto) y un hombre socialmente comprometido (al acercarse al sufrimiento social del subcontinente y acompañar con simpatía el drama sinuoso de sus revoluciones). (González 2000: 416)
\end{abstract}

Sosa Villada recobra esa mirada sensible para narrar su mundo travesti, y pone a funcionar la equivalencia de desigualdad que define la relación de fuerzas entre los mundos -como se los denominó en los sesenta-, desarrollado y subdesarrollado; en la relación también desigual entre el "mundo blanco" de la sociedad patriarcal hetero cis capitalista, y el mundo marginal de las comunidades

Revista Zona Franca- Centro de estudios interdisciplinario sobre las mujeres (CEIM)- Maestría poder y sociedad desde la problemática de género (MG), Rosario, Argentina. ISSN, 2545-6504 http://zonafranca.unr.edu.ar/index.php/ZonaFrancal Número 28 (2020). 
travestis trans latinoamericanas. Esa relación signada por la injusticia, la violencia, la miseria y el sometimiento se representa en la novela como una historia fracturada, en la que conviven planos temporales muy diversos en un único presente que los disuelve y los aúna en una única masa temporal, provocando efectos "maravillosos".

El realismo mágico de Las malas superpone la fantasía de los cuentos de princesas, como también observamos en Madame Satã, a la realidad de la discriminación y la pobreza que definen su existencia. Con bijouterie barata, plataformas de acrílico, pelucas y lentejuelas; pero también con alegría, sororidad y amor, la novela inventa un mundo brillante y luminoso. A la fantasía de los cuentos de princesas se suman, además, mitos, leyendas, creencias representativas de los pueblos originarios americanos, como la leyenda del lobizón. A través de esa fabulosa combinación, Sosa Villada logra concebir la discordancia como resultado de un efectivo acontecer histórico. Pero si el "realismo mágico" fue alimentado por el "barroco americano", como afirma Horacio González (2000: 413), en el "realismo marabrilloso" de las Las malas subyace el "neobarroso" de Néstor Perlongher. Allí, donde se cruzan la serie política y la sexual para hacer visible la violencia en un momento histórico determinado, por medio de una poética exuberante de acumulación y exceso que provoca asombro antes que empatía.

La búsqueda de una identidad, como un signo revolucionario, diría Cortázar ${ }^{4}$. La operación que lleva adelante Sosa Villada en la novela consiste en hacer del estigma un rasgo de exotismo. Vale decir, hacer de aquello que genera rechazo por ajeno o exterior, objeto de fascinación justamente en función de su carácter extraño. De modo tal, que lo que la mirada hetero cis normativa y patriarcal señala en los sujetos travestis y trans, marcándolos como un Otro -monstruoso, anormal, enfermo, desviado-, que los condena a la marginalidad, en la novela pasa a ser aquello que las hace únicas y especiales. Es decir, que esta operación no busca negar ese estigma, más bien pone a funcionar la doble valencia del término que

${ }^{4}$ En entrevista realizada por Joaquín Soler Serrano durante el año 1977 para el programa televisivo "A fondo".

Revista Zona Franca- Centro de estudios interdisciplinario sobre las mujeres (CEIM)- Maestría poder y sociedad desde la problemática de género (MG), Rosario, Argentina. ISSN, 2545-6504 http://zonafranca.unr.edu.ar/index.php/ZonaFrancal Número 28 (2020). 
refiere tanto a una marca de la injuria como a una marca de santidad. De esta forma, el desplazamiento que se produce convierte lo "antinatural" -que la mirada biologicista y religiosa esgrimen- en sobrenatural:

Pero las travestis perras del Parque Sarmiento de la Ciudad de Córdoba escuchan mucho más que cualquier vulgar humano (...) Y (con el grito de la Tía Encarna) se ponen en alerta, la piel de gallina, los pelos erizados, las branquias abiertas, las fauces en tensión. (Sosa Villada 2019: 14)

El exotismo pone en valor el mundo travesti al crear un verosímil real maravilloso que lo dota de poesía, magia y mística, sin ocultar a la vez sus aspectos violentos o tristes. La apuesta radica en la exageración y el exceso, tanto de naturaleza como de excepcionalidad.

En la descripción de ese mundo y sus seres, la catalogación y clasificación de las distintas travestis, lejos de ser totalizante, supone una variedad infinita de posibilidades, tantas como travestis existen en el mundo. Así es que la taxonomía de cada pueblo, especie, comunidad o individuo tiene como objeto conocer sus singularidades, darles vida en ese mundo ficcional, y crear un archivo que no permite fijar sentidos, identidades, tipos porque se multiplica a cada instante.

Como dijimos, el mundo mágico travesti que se construye en la novela coexiste con el mundo ordinario de los demás, aunque con otra temporalidad, acelerada: la Tía Encarna tenía ciento setenta y ocho años porque un año travesti era equivalente a siete años de cualquier mortal (13); y cíclica: "Así es noche tras noche". (12). En los momentos en que ambos mundos no interfieren, el travesti es un mundo feliz: "Aquella fue la era de las flores en nuestro clan, a pesar de la condena a muerte de la que éramos víctimas. Fue la era de olernos entre nosotras como perras y polinizarnos" (23). Pero cuando se cruzan, no tiene chances de sobrevivir, dado que la vida de una travesti latinoamericana es siempre la crónica de una muerte anunciada: "Eso somos como país también, el daño sin tregua al cuerpo de las travestis. La huella dejada en determinados cuerpos, de manera injusta, azarosa y evitable, esa huella de odio" (19).

Revista Zona Franca- Centro de estudios interdisciplinario sobre las mujeres (CEIM)- Maestría poder y sociedad desde la problemática de género (MG), Rosario, Argentina. ISSN, 2545-6504 http://zonafranca.unr.edu.ar/index.php/ZonaFranca| Número 28 (2020). 


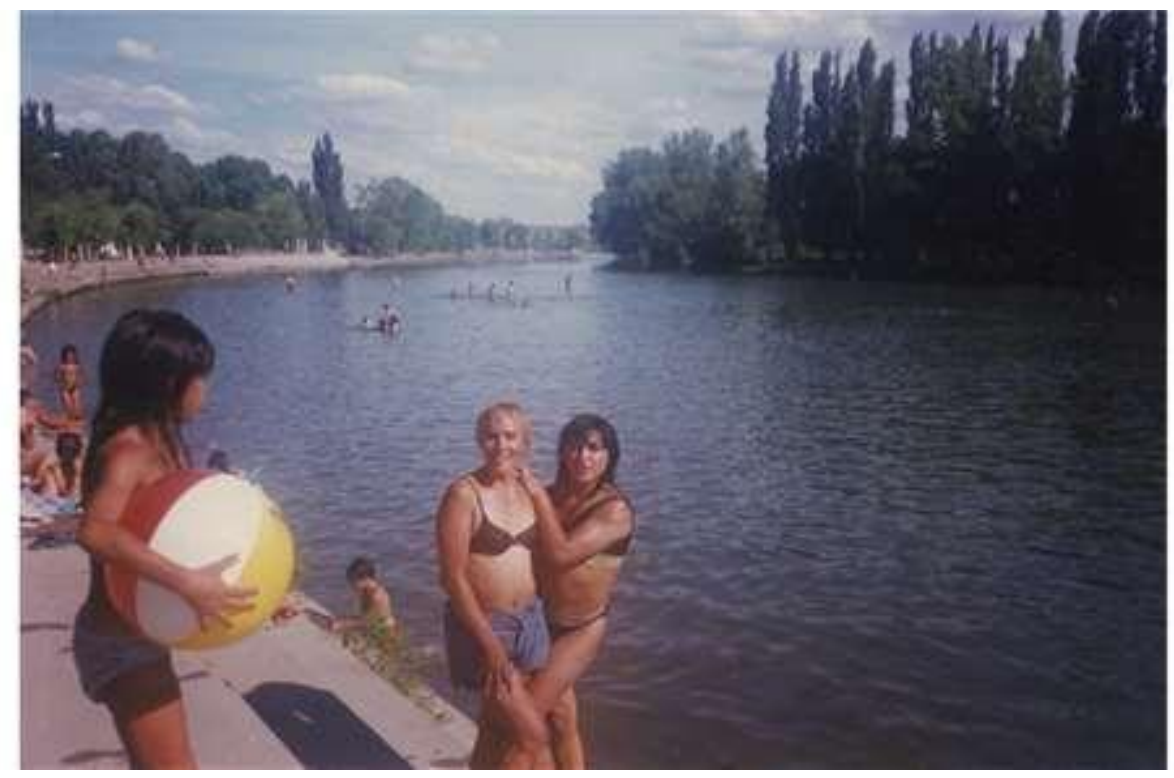

Archivo de Memoria Trans

El cuerpo de las travestis debe entenderse, por lo tanto, como mapa y archivo de la violencia de Estado, así como de la que ejercen los medios y los ciudadanos privilegiados: "Si alguien quisiera hacer un registro exacto de esa mierda, entonces debería ver el cuerpo de la tía Encarna" (19). Ese mapa del odio que se superpone al mapa de la patria, se encarna en el cuerpo de las travestis y diseña una cartografía de múltiples dimensiones territoriales: "aquel patio hermosamente dominado por la vegetación, aquel patio que era la continuación del Parque, tal como el cuerpo de ella (la Tía Encarna, "madre de todos los monstruos") era la continuación de la guerra" (19). Entre la oscuridad del parque y la intimidad de la casa de la tía Encarna, se traza la ruta que las mantiene a salvo de las miradas de la sociedad que las excluye y les niega su derecho a existir. $Y$ cuando esa ruta desaparece, la magia se termina, el clan se disgrega y cada una queda librada al desamparo y la violencia de su destino travesti.

La casa de la tía Encarna se vuelve peligrosa por la presencia del bebé que encontraron y salvaron:

Revista Zona Franca- Centro de estudios interdisciplinario sobre las mujeres (CEIM)- Maestría poder y sociedad desde la problemática de género (MG), Rosario, Argentina. ISSN, 2545-6504 http://zonafranca.unr.edu.ar/index.php/ZonaFrancal Número 28 (2020). 
La policía va a hacer rugir sus sirenas, va a usar sus armas contra las travestis, van a gritar los noticieros, van a prenderse fuego las redacciones, va a clamar la sociedad, siempre dispuesta al linchamiento. La infancia y las travestis son incompatibles. (16)

Y el Parque Sarmiento ya no puede ser su lugar de trabajo porque la policía las echa definitivamente para ocultarlas de la mirada del electorado urbano:

No pueden mirar otra cosa. Eso logramos las travestis: atraer todas las miradas del mundo. Nadie puede sustraerse al hechizo de un hombre vestido de mujer, esos maricones que van demasiado lejos, esos degenerados que acaparan las miradas. (115)

Es entonces cuando se rompe la comunidad. A diferencia de lo que Oscar Masotta (2008) señala sobre los personajes de Roberto Arlt, como parte de una comunidad de humillados donde el lazo es el odio, que provoca el rechazo de unos hacia otros; en Las malas, Ixs humilladxs sí conforman comunidad. Se reconocen en Ix otrx y se abrazan. Manada, aquelarre, clan o familia, "eso que sucede en esa casa es complicidad de huérfanas" (16). Así acontece entre las travestis, pero también con la mujer de los perros del Parque, con la embarazada del grupo, o con los Hombres sin Cabeza: "Ellos dejaban en claro que se enamoraban de nosotras porque a nuestro lado era más fácil compartir el trauma, dejarlo trepar por las paredes o recluirlo cuando hacía falta" (25). De ese reconocimiento con Ixs otrxs nace la comprensión -"un amor mucho mayor" (123)-, y eso les permite definir su identidad, que se vuelve colectiva y tiene una enorme potencia política:

Me pregunto qué habría pasado si, en vez de mandar la rabia a los más hondo de nuestra alma travesti, nos hubiéramos organizado. ¿Qué pasó, en cambio? ¿Adónde nos llevó tragarnos el veneno? A morir jóvenes. Porque, salvo en esos súbitos y rabiosos estallidos fratricidas, las travestis no matábamos ni una mosca. (81)

En el mundo real, de todos los días, el estigma vuelve como injuria y es necesario poner en práctica "el don de la transparencia" para sobrevivir. Porque en el espacio público y a la luz del día ellas no tienen derecho a existir: "Tan solo con

Revista Zona Franca- Centro de estudios interdisciplinario sobre las mujeres (CEIM)- Maestría poder y sociedad desde la problemática de género (MG), Rosario, Argentina. ISSN, 2545-6504 http://zonafranca.unr.edu.ar/index.php/ZonaFranca| Número 28 (2020). 
agachar la cabeza las travestis logran el don de la transparencia que les ha sido dado en el momento de su bautismo" (16).

Es la ficción la que habilita otros momentos de la vida trans, fuera de la noche, el delito, el escándalo o el carnaval. Es la ficción la que crea una cartografía para imaginar futuros posibles en medio del dolor, como ese mensaje del novio sin cabeza de la Tía Encarna, que decía "que había sido feliz, que recordaba su piel llena de moretones como un mapa en el que se aprende a soñar con futuros viajes" (31).

\section{Conclusión: Esbozos de un archivo transfeminista}

El recorrido termina acá, pero el archivo no se clausura, puede seguir llenándose de otros documentos, testimonios y ficciones travestis trans que tengan en común "el poder de liberar a las imágenes de su uso perverso" (Rolnik 2008: 7). En este sentido, los materiales que pusimos en relación en este trabajo suponen una forma de intervención poético-política que rompe el determinismo latinoamericano de Ixs sujetxs trans y habilita la imaginación de otros destinos posibles. En la reconfiguración del pasado que anuda el presente y reformula el futuro, en los espacios híbridos que desdibujan las fronteras geográficas y los límites de las texturas corporales, se superponen las huellas del odio con la felicidad, la escasa esperanza de vida con el disfrute, la humillación con la dignidad, y se recupera la densidad de la existencia.

Es un archivo que está inevitablemente ligado al trauma, pero que no por eso implica diagnósticos médicos ni víctimas aunque, por su propia naturaleza, requiere estrategias inusuales de representación (Cvetkovich, 2003). En la medida que el trauma pone en cuestión y reformula las reglas, la lógica y las fórmulas de entender convencionalmente un archivo en términos de documento y memoria, habilita la invención de formas expresivas nuevas, alternativas, colectivas y públicas, diluyendo la frontera entre vida emocional y vida política. De este modo, tomando el concepto de Ann Cvertkovich, podemos establecer que el archivo transfeminista es

Revista Zona Franca- Centro de estudios interdisciplinario sobre las mujeres (CEIM)- Maestría poder y sociedad desde la problemática de género (MG), Rosario, Argentina. ISSN, 2545-6504 http://zonafranca.unr.edu.ar/index.php/ZonaFrancal Número 28 (2020). 
un archivo de sentimientos que alberga en sí diversas formas del amor, la rabia, la vergüenza. En este mismo sentido, trae a la superficie y cobra más relevancia un conocimiento emocional a partir de la necesidad de situar la vida íntima en relación con el clasismo, el racismo y otras formas de opresión como el cisexismo y la heterosexualidad obligatoria.

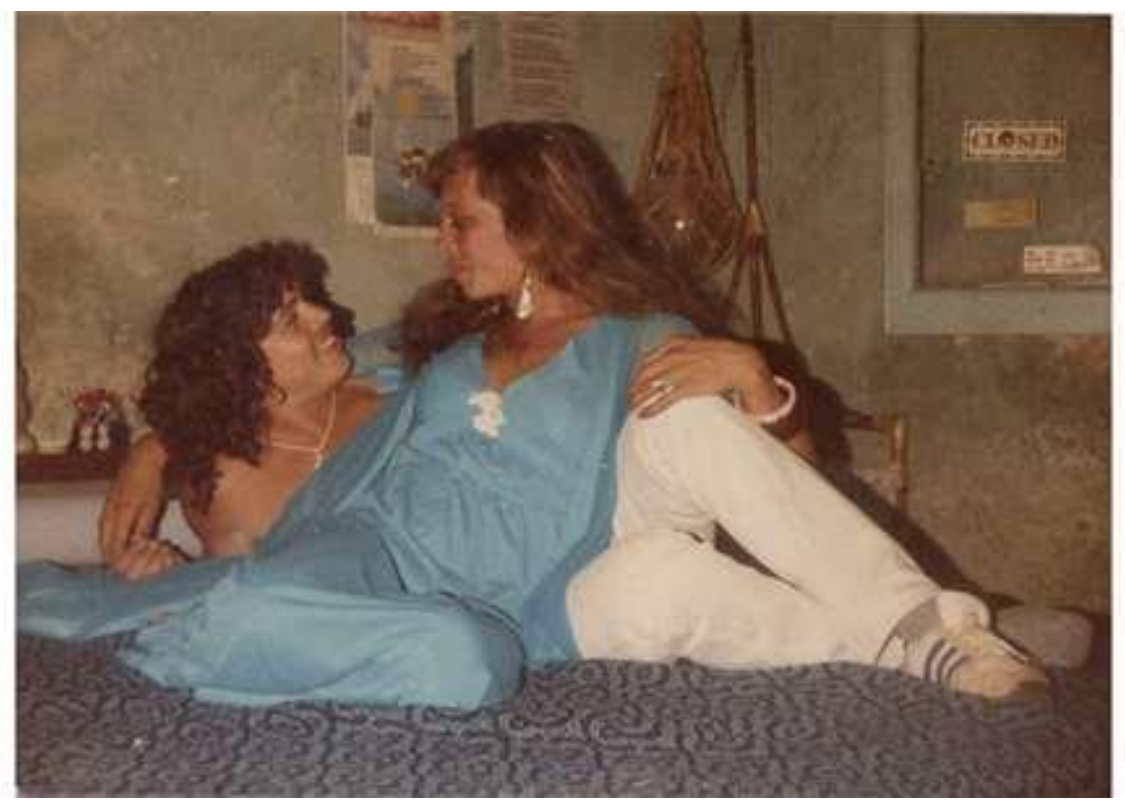

Archivo de Memoria Trans

El montaje que supone el armado de este archivo resuena en el diseño performático de los cuerpos travestis, en la construcción del devenir de una identidad política que se "monta" con las luchas y las resistencias de una experiencia común. $\mathrm{Y}$ por modos emergentes, experimentales y creativos de agenciamiento y movilización. Al contrario de los efectos que produce el archivo biomédico-jurídico, que es, además de patologizante y criminalizante, profundamente desmovilizante. El archivo transfeminista rompe con las imágenes cristalizadas y provoca una movilización de flujos detenidos sobre los cuerpos trans por los modos en que se presentan los biografemas, las experiencias cotidianas, y 
porque el propio archivo funciona como un campo de experimentación emancipatoria.

De esta manera, aunque cada foto, carta o relato tienen una protagonista, una voz que narra desde la experiencia y la imaginación, las historias que componen el archivo transfeminista nunca cuentan una historia individual, en cada historia se cifra un sujeto colectivo y un compromiso con Ixs otrxs. Y, por eso, se imprime una política de la subjetividad que reformula el tiempo, el espacio y las lógicas afectivas que organizan un mundo humano y más que humano.

\section{Bibliografía}

AMT, Archivo de la Memoria Trans. Página web oficial: https://archivotrans.com.ar/colabora

"Archivo de la Memoria Trans - Entrevistas", parte de la muestra "Esta se fue, a esta la mataron, esta murió", marzo de 2018, 21:44.

"Siempre estuvimos ahí", muestra digital que nos invita a reflexionar sobre la realidad trans. En Diputados Argentina, del martes 21 de julio al 30 de julio de 2020. En línea: https://www.diputados.gob.ar/secparl/dcultura/agenda/2020/julio/trans

AGAMBEN, Giorgio (2002) Lo que queda de Auschwitz. El archivo y el testigo. Homo sacer III, Valencia, Pre-textos.

AïNOUZ, Karim (2002). Madame Satã, Brasil, 1:39:56.

BERKINS, Lohana (2006) “Travestis: una identidad política”. En Emisferica 42, Hemispheric Institute, en línea: https://hemisphericinstitute.org/es/emisferica-42/42-review-essays/lohana-berkins.html

CONTRERAS, Tania Medalla (2012). "Cine, historia y representaciones de la marginalidad: Ciudad, cuerpo y narración en 'Madame Satá'. En III Congreso Internacional de la Asociación Argentina de Estudios de Cine y Audiovisual, AsAECA. En línea: http://www.asaeca.org/aactas/medalla contreras tania ponencia.pdf

CORTÁZAR, Julio (1977). Entrevista realizada en el programa "A fondo", conducido por Joaquín Soler Serrano. Página web de RTVE:

Revista Zona Franca- Centro de estudios interdisciplinario sobre las mujeres (CEIM)- Maestría poder y sociedad desde la problemática de género (MG), Rosario, Argentina. ISSN, 2545-6504 http://zonafranca.unr.edu.ar/index.php/ZonaFranca| Número 28 (2020). 


\section{https://www.rtve.es/alacarta/videos/a-fondo/entrevista-julio-cortazar-programa-}

\section{fondo/1051583/}

CVETKOVICH, Ann (2003) Un archivo de sentimientos. Trauma, sexualidad y culturas públicas lesbianas, Barcelona, Edicions Bellaterra.

DERRIDA, Jaques (1997) Mal de archivo: una impresión freudiana, Madrid, Editorial Trotta.

DIDI-HUBERMAN, Georges (2012) "El archivo arde”. Traducción de Juan Antonio Ennis para uso de la cátedra de Filología Hispánica de la Universidad Nacional de La Plata. En línea: https://filologiaun/p.files.wordpress.com/2012/05/elarchivo-arde1.pdf

FOUCAULT, Michel (1992). "Nietzsche, la genealogía, la historia". En Microfísica del poder, Madrid, La Piqueta. . (1997 [1970]) La arqueología del saber, México, Siglo XXI.

GONZÁLEZ, Horacio (2000). "El boom: rastros de una palabra en la narrativa y la crítica argentina", en Historia crítica de la literatura argentina, Vol. 11, Buenos Aires, Emecé.

GUASCH, Anna Maria (2011) Arte y archivo 1920-2010. Genealogías, tipologías y doscontinuidades, Madrid, Akal.

MASOTTA, Oscar (2008) Sexo y traición en Roberto Arlt, Buenos Aires, Eterna Cadencia.

ROLNIK, Suely (2008). "Furor de Archivo". En Revista Colombiana de Filosofía de la Ciencia, vol. IX, núm. 18-19, pp. 9-22.

SEKULA, Allan. (1986) "The Body and the Archive". En October, Vol. 39, Winter, 3-64.

SOSA VILLADA, Camila (2019) Las malas, Buenos Aires, Tusquets. 